\title{
Effect of Grewia Venusta FRESEN Mucilage on the Proximate Composition, Physical and Sensory Properties of Bread Produced from Wheat and Cassava Composite Flours
}

\author{
Arubi P. Alobo ${ }^{*}$ And Gibson L. Arueya ${ }^{a}$ \\ ${ }^{\text {a }}$ Department of Food Technology, University of Ibadan, Nigeria \\ ${ }^{*}$ Corresponding author \\ apalobo@gmail.com \\ TEL: +2348059454495
}

Received: 8 November 2016; Published online: 18 October 2017

\begin{abstract}
Wheat and cassava composite breads are generally associated with volume and textural defects in contrast with the traditional wheat based variants. Efforts to mitigate this challenge through use of synthetic additives have been unsuccessful owing to safety concerns. The objective of this study was to explore Grewia venusta mucilage as a potential natural additive in wheat-cassava composite bread production. Sweet cassava flour was used to replace wheat flour at 100: 0 (control), 90:10, 80:20 and 70:30\% ratios in bread making. Aqueous extract of $G$. venusta stem bark was oven dried $\left(50 \pm 3{ }^{\circ} \mathrm{C}\right)$, milled and added at $0,1.0$ and $2.0 \%(\mathrm{w} / \mathrm{w})$ to the flour mixtures. These, along with other conventional inputs were mixed, and used to produce bread. Proximate compositions, physical and sensory properties of the bread loaves were evaluated. Cassava flour inclusion resulted in significant $(\mathrm{P} \leq 0.05)$ decrease in the protein content of the control from $18.1 \%$ to $12.1 \%(90: 10 \%), 11.5 \%(80: 20 \%)$ and $9.9 \%(70: 30 \%)$. Addition of mucilage marginally increased the protein and dietary fibre contents of the loaves. Loaves containing 1-2\% mucilage were more regular in shape with smoother crust than those without mucilage. Cassava flour addition at 10\%, 20\% and $30 \%$ decreased loaf height from 6.0 $\mathrm{cm}$ to $5.8 \mathrm{~cm}, 5.7 \mathrm{~cm}$ and $5.5 \mathrm{~cm}$, as well as loaf volume from $815.5 \mathrm{~cm}^{3}$ to $783.1 \mathrm{~cm}^{3}, 776.8 \mathrm{~cm}^{3}$ and $744.5 \mathrm{~cm}^{3}$, respectively. Mucilage inclusion resulted in increased heights and volumes of the loaves and reduced weights of loaf fragments upon slicing. The mucilage significantly improved the texture of the bread loaves.
\end{abstract}

Keywords: Bread quality; Cassava flour; Grewia mucilage; physical and sensory properties

\section{Introduction}

Bread is an important staple food in both developing and developed countries. It is traditionally produced from wheat flour and other ingredients like yeast, salt, fat and water. In most situations wheat requirements are largely met through imports and usually at the expense of scarce foreign exchange. A recent trend in the bakery industry in most non-wheat producing countries is the replacement of wheat flour with composite flours and blends of flours or meals from locally cultivated crops other than wheat to produce products such as bread, biscuit, cake and doughnut (Eduardo, Svanberg, Oliveia, \& Ahrne, 2013; Ohimain, 2014a; Koko, Kouame, Assidjo, \& Amani, 2014). Due to economic recession, attention has been particularly focused on substitution of imported wheat flour with flour from other sources in bread baking (Sanni et al., 2005; Oladunmoye, Akinoso, \& Olapade, 2010; Ohimain, 2014b). Nwanekezi (2013) stated that 
blending of non-wheat flour with wheat flour decreases the concentration of gluten proteins in wheat. Yeast leavened products such as bread lose their quality, especially volume and texture when their gluten level is decreased. Such substitution would require the use of ingredients and additives with different characteristics to make up for the functional and quality attributes lost when wheat flour is reduced. Many chemical and synthetic additives with various properties have been used in the bakery industry to improve the baking properties of flours (Asghar, Anjum, Tariq, \& Hussain, 2005; Kohajdova, Karovicova, \& Schmidt, 2009). There is, however an increasing concern over the future health risks associated with the use of the additives. For example, potassium bromate, which has been used for decades as a flour improver has now been found to be carcinogenic (Badifu, Chima, Ajayi, \& Ogori, 2005). Plant materials serve as alternatives to chemical and synthetic additives as well as imported products because of local availability, environment friendliness and lower price (Kumar, Sati, \& Singh, 2011). Against this backdrop, there is need to promote the use of natural hydrocolloids, like gums and mucilages of plant origin in breadmaking. Nigeria, as with other developing countries in the tropics, possesses large fertile arable lands where food crops like cassava, maize, rice, millet and sorghum are grown in large quantities. The availability of these crops could enhance their utilization as components in composite flours. The use of wheat and cassava composite flours with such mucilages in bread making in particular could help developing countries decrease wheat importation and reduce expenses on imports. It could also encourage diversification in the use of cassava as well as make bread and other bakery products affordable by low income earners who constitute the larger population of consumers in the countries. $\mathrm{Mu}-$ cilage and gums obtained from plants have been used as alternatives to hydrocolloids produced by biosynthetic or fermentative processes (Wang \& Wang, 2013). Grewia venusta mucilage has been used in the preparation of fried cake (akara) from bambara groundnuts in parts of Nigeria to combat noticeable problems such as poor swelling and absence of air pockets in the cake. This research examined the effect of Grewia venusta mucilage extract on the performance of wheat and cassava flour mixtures in bread production.

\section{Materials and Methods}

\subsection{Extraction of mucilage}

Mucilage in stems of Grewia venusta trees cut from Ajaokuta, Kogi State, Nigeria was extracted using the procedure described by Ogori and Gana (2014) with modifications. The stems were thoroughly cleaned by scraping off the powdery brownish bark with knife and then washed in water. The washed stem barks were cut into short pieces about $20 \mathrm{~cm}$ long, reduced to thin strips and weighed to about $700 \mathrm{~g}$. The pieces were mixed with $1.5 \mathrm{~L}$ of clean water and squeezed to release the mucilage. Further extraction was performed with additional $1.5 \mathrm{~L}$ of water. The mucilage was then filtered through a double-folded muslin cloth to separate the mucilage from the strips of bark. The mucilage was dried (thin layer) in an air oven (Gallenkamp BS 200, England) at $50 \pm 3{ }^{\circ} \mathrm{C}$ to a moisture content of $5.0 \%$, milled and sieved using a laboratory test sieve of $80 \mathrm{~mm}$ mesh.

\subsection{Preparation of wheat: cassava composite flours for bread production}

Cassava flour was prepared using a sweet cassava variety following the IITA - International Institute of Tropical Agriculture (2005) procedure with minor modifications. The cassava roots were obtained fresh from the farm and sorted. The fresh, mature cassava roots without rot were peeled, washed with clean, potable water and drained. The peeled roots were sliced into flakes using a knife and blanched at $60{ }^{\circ} \mathrm{C}$ for $30 \mathrm{~min}$ utes. The flakes were then dried in a draft air oven at $50 \pm 3{ }^{\circ} \mathrm{C}$ for 24 hours. The dried flakes (6.2\% moisture) were milled and sieved (80 $\mathrm{mm}$ mesh) to obtain cassava flour. Wheat $(6.5 \%$ moisture) (Golden Penny, Nigeria) and cassava composite flours were prepared in the ratios of 100:0\%, 90:10\%, 80:20\% and 70:30\% on a weight basis. 


\subsection{Production of bread}

he straight dough method of bread making (Sedlacek \& Horcicka, 2011) was used with slight modifications for the production of bread. Wheat and cassava composite flours (200 g), as above, were mixed with $0 \%, 1.0 \%$, and $2.0 \%$ (w/w) Grewia venusta mucilage powder, respectively. The proportions of the other ingredients used were $6.0 \mathrm{~g}$ yeast, $3.2 \mathrm{~g}$ salt, $5.0 \mathrm{~g}$ margarine, $14.5 \mathrm{~g}$ sugar and $125 \mathrm{~mL}$ water. The ingredients were weighed accurately using an electronic top loading balance. The ingredients were mixed to homogeneity and kneaded for $20 \pm 2$ minutes using a dough kneader (Masterchef double arm dough mixer, China). The kneaded dough was spread on a smooth surface and cut into uniform weights. The cut dough pieces were moulded, placed in oiled baking pans and then proofed at $36 \pm 2{ }^{\circ} \mathrm{C}$ for 2 hours. They were then baked in an oven at $235-240{ }^{\circ} \mathrm{C}$ for $32 \pm 2$ minutes. The baked bread loaves were removed from the pans and allowed to cool for about 20 minutes. They were sliced using a bread slicer, packaged in low density polyethylene pouches until analysed.

\subsection{Physical measurements of bread loaves}

The weight of three bread loaves was measured using a top loading balance and mean values were recorded according to the method of AsifUl-Alam, Islam, Hoque, and Monalisa (2014). The length, width and height were measured at three different points using a ruler and mean values were calculated. Volume was computed using the values for length, height and width according to the method of Badifu et al. (2005). Bread specific volume was determined by dividing loaf volume by weight (Igbabul, Num, \& Amove, 2014). Bread crumb fragments were collected and weighed after the loaves were sliced using a bread slicing machine. Two loaves were used per batch and mean values were computed. The air spaces in the bread loaves were observed visually after the loaves had been sliced into halves.

\subsection{Determination of proximate composition of bread loaves}

The moisture, protein, dietary fibre, ash, fat and carbohydrate contents of the bread containing $G$. venusta mucilage were determined as reported earlier (AOAC - International, Association of Official Analytical Chemists, 2005). Duplicate samples (2 g each) were used for the determinations.

\subsection{Sensory evaluation of bread}

The bread samples were evaluated for colour, taste, flavour, texture and overall acceptability by a 10 -member panel comprising male and female subjects who were familiar with bread. Only panellists that were free from any physical and psychological conditions that might affect their judgement were selected (Hashmi, 2007; Svensson, 2012). The panellists were trained prior to the commencement of the evaluation for an understanding of the attributes to be assessed and the scale to be use. The bread loaves were evaluated using a modified 7-point hedonic scale according to the method of Singh-Ackbarali and Maharaj (2014). This modification was well explained to the panellists so that they understood the scale points. The assessment was conducted under fluorescent illumination inside isolated booths within an air-conditioned sensory evaluation laboratory.

\section{7 $\quad$ Statistical analysis}

Experimental and sensory data were statistically analysed by analysis of variance (ANOVA) and means were compared using least significant difference (LSD) at $P \leq 0.05$ level according to the method of Steel, Steel, Torrie, and Dickey (1997).

\section{Results and Discussion}

\subsection{Size Characteristics}

There were differences in the appearance of the bread crusts due to cassava flour and Grewia venusta mucilage addition (Fig. 1). Whereas the crust of the $100 \%$ wheat flour bread and the 
Quality of bread from wheat-cassava flours $\mid 195$

Table 1: Effect of Grewia venusta mucilage on the physical properties of bread loaves produced from wheat-cassava composite

\begin{tabular}{lllllllll}
\hline $\begin{array}{l}\text { WF: CF } \\
(\%)\end{array}$ & GG & $\begin{array}{l}\text { Weight } \\
(\mathrm{g})\end{array}$ & $\begin{array}{l}\text { Height } \\
(\mathrm{cm})\end{array}$ & $\begin{array}{l}\text { Width } \\
(\mathrm{cm})\end{array}$ & $\begin{array}{l}\text { Length } \\
(\mathrm{cm})\end{array}$ & $\begin{array}{l}\text { Volume } \\
\left(\mathrm{cm}^{3}\right)\end{array}$ & $\begin{array}{l}\text { Specific volume } \\
\left(\mathrm{cm}^{3} / \mathrm{g}\right)\end{array}$ & $\begin{array}{l}\text { Crumb } \\
\text { fragments }(\mathrm{g})\end{array}$ \\
\hline $100: 0$ & $0^{*}$ & $340.0 \pm 0.1^{g}$ & $6.0 \pm 0.2^{c}$ & $8.6 \pm 0.1$ & $15.8 \pm 0.2$ & $815.5 \pm 0.3^{e}$ & $2.4 \pm 0.1^{d}$ & $2.2 \pm 0.2^{a}$ \\
$90: 10$ & 0 & $341.2 \pm 0.3^{f}$ & $5.8 \pm 0.4^{d}$ & $8.6 \pm 0.0$ & $15.7 \pm 0.1$ & $783.1 \pm 0.2^{g}$ & $2.3 \pm 0.2^{e}$ & $2.1 \pm 0.4^{a}$ \\
$90: 10$ & 1.0 & $341.9 \pm 0.1^{e}$ & $6.2 \pm 0.2^{b}$ & $8.7 \pm 0.2$ & $15.7 \pm 0.1$ & $846.9 \pm 0.1^{b}$ & $2.5 \pm 0.3^{c}$ & $1.2 \pm 0.4^{b}$ \\
$90: 10$ & 2.0 & $342.8 \pm 0.2^{d}$ & $7.1 \pm 0.2^{a}$ & $8.7 \pm 0.2$ & $15.8 \pm 0.3$ & $976.0 \pm 0.3^{a}$ & $2.8 \pm 0.1^{a}$ & $0.2 \pm 0.2^{c d}$ \\
$80: 20$ & 0 & $342.0 \pm 0.1^{e}$ & $5.7 \pm 0.2^{d e}$ & $8.6 \pm 0.0$ & $15.7 \pm 0.2$ & $769.6 \pm 0.1^{h}$ & $2.6 \pm 0.2^{b}$ & $2.2 \pm 0.3^{a}$ \\
$80: 20$ & 1.0 & $344.7 \pm 0.3^{c}$ & $6.1 \pm 0.1^{b e}$ & $8.7 \pm 0.0$ & $15.8 \pm 0.2$ & $838.5 \pm 0.2^{d}$ & $2.4 \pm 0.2^{d}$ & $0.8 \pm 0,4^{b c}$ \\
$80: 20$ & 2.0 & $346.3 \pm 0.0^{b}$ & $6.3 \pm 0.4^{b}$ & $8.5 \pm 0.3$ & $15.7 \pm 0.1$ & $840.7 \pm 0.2^{c}$ & $2.4 \pm 0.4^{d}$ & $0.2 \pm 0.1^{c d}$ \\
$70: 30$ & 0 & $344.5 \pm 0.4^{c}$ & $5.5 \pm 0.5^{e}$ & $8.7 \pm 0.3$ & $15.5 \pm 0.3$ & $741.7 \pm 0.4^{i}$ & $2.2 \pm 0.2^{f}$ & $2.1 \pm 0.2^{a}$ \\
$70: 30$ & 1.0 & $346.8 \pm 0.2^{b}$ & $5.9 \pm 0.3^{d}$ & $8.5 \pm 0.4$ & $15.6 \pm 0.4$ & $782.0 \pm 0.3^{g}$ & $2.3 \pm 0.3^{e}$ & $0.5 \pm 0.1^{c}$ \\
$70: 30$ & 2.0 & $349.0 \pm 0.2^{a}$ & $6.0 \pm 0.5^{c}$ & $8.5 \pm 0.3$ & $15.6 \pm 0.2$ & $795.6 \pm 0.2^{f}$ & $2.3 \pm 0.4^{e}$ & $0.2 \pm 0.2^{c d}$ \\
LSD & & 0.6 & 0.2 & & & 4.0 & 0.04 & 0.4 \\
\hline
\end{tabular}

alues are means $\pm \mathrm{SD}$ of triplicate determinations. Means in a given column with the same or no superscripts are not significantly different $(P \geq 0.05)$.

$\mathrm{WF}=$ Wheat flour, $\mathrm{CF}=$ Cassava flour, $\mathrm{GG}=$ Grewia mucilage powder (\% of flour blend).

$\mathrm{LSD}=$ Least significant difference. $\mathrm{SD}=$ Standard deviation

*Control.

90: $10 \%$ wheat-cassava flour bread without mucilage appeared slightly wrinkled, the crust of the bread containing 1 and $2 \%$ mucilage were more regular and smooth. Bread loaves produced from 80: $20 \%$ wheat and cassava flour blend had a slightly rough crust compared to the smooth appearance of the crust of the bread from the 70: 30\% flour blend. Kohajdova et al. (2009) reported that gum arabic possessed good adhesive properties that improved cell wall structure, which predisposed the gum for use in baked products. Adhesiveness due to Grewia venusta mucilage may have played a role in the smoothness of the bread crust in the present study. The physical parameters of the bread loaves containing Grewia mucilage are shown in Table 1. Loaf weight increased with increasing cassava flour in the blend. There was, however, no apparent effect of the Grewia mucilage on the weight of the bread loaves prepared from the flour blends. Cassava flour inclusion resulted in the decrease of loaf height and volume relative to the control wheat bread. On the other hand, addition of Grewia mucilage to the flour mixtures resulted in bread loaves with increased heights and volumes beyond those for the blends without mucilage (Fig. 2). The trend exhibited in both loaf volume and specific loaf volume was similar to that for the height. Eduardo et al. (2013) attributed reduced bread volume with cassava inclusion in a flour mixture to reduced flour strength and lower ability of the gluten network to enclose carbon dioxide during proofing. Studies have shown that loaf volume is affected by the quantity and quality of protein in the flour used for baking and also by proofing time, baking time and baking temperature (Shittu, Raji, \& Sanni, 2007). Cassava flour lacks gluten and is therefore unable upon hydration to form the cohesive visco-elastic dough capable of forming the typical fixed open foam structure of bread (Eriksson, Koch, Tortoe, Konor, \& Oduro-Yeboah, 2014). A number of researchers have reported similar findings (Almazan, 1990; Defloor, Nys, \& Delcour, 1993; Khalil, Mansour, \& Dawoud, 2000). The increasing bread volume due to Grewia mucilage addition in the present study can be attributed to improvement of dough development and gas retention by increasing dough viscosity and stability as reported by Delcour, Vanhamel, and Hoseney (1991) and Rojas, Rosell, and de Barber (1999). Grewia venusta mucilage contains hydrophobic groups on the account of its content of carboxyl groups of sugars (Nenonene, Koba, Sanda, \& Rigal, 2009; Nep \& Conway, 2010) that might reduce interfacial activity with gluten, thus forming gel networks that could enclose carbon dioxide during the bread making process. The mu- 

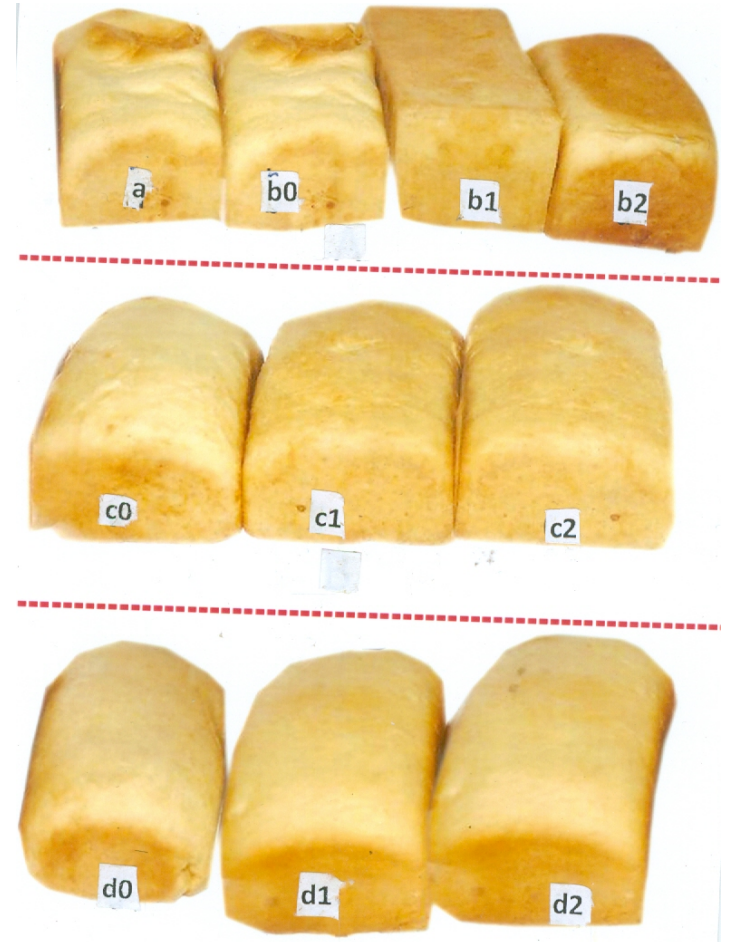

Figure 1: Bread loaves from wheat-cassava flour blends containing different levels $(\%, \mathrm{w} / \mathrm{w})$ of Grewia venusta mucilage

$\mathrm{a}=100 \%$ wheat flour (Control)

$\mathrm{b}=90: 10 \%$ wheat-cassava flour blends

$\mathrm{c}=80: 20 \%$ wheat-cassava flour blends

$\mathrm{d}=70: 30 \%$ wheat-cassava flour blends

Number 0,1 and 2 represent $0 \%, 1 \%$ and $2 \%$ mucilage, respectively

cilage has also been shown in a related and ongoing Ph.D research projectto increase the paste viscosity of wheat and cassava composite flours during heating (Alobo, 2016 unpublished). The increased viscosity and, probably gel network of the mucilage may have strengthened the gasholding properties of the expanding cells in the dough. This may have resulted in the improved loaf volume. According to Kohajdova et al. (2009), the use of small quantities of hydrocolloids is expected to enhance the water retention and loaf volume of bread. Miller and Hoseney (1993) reported that xanthan gum contributed to uniform distribution of moisture throughout cake batter and improved the volume and crumb structure of the cake baked from the batter. In addition, the viscosity that developed helped the batter to encapsulate gas evolved by fast-acting
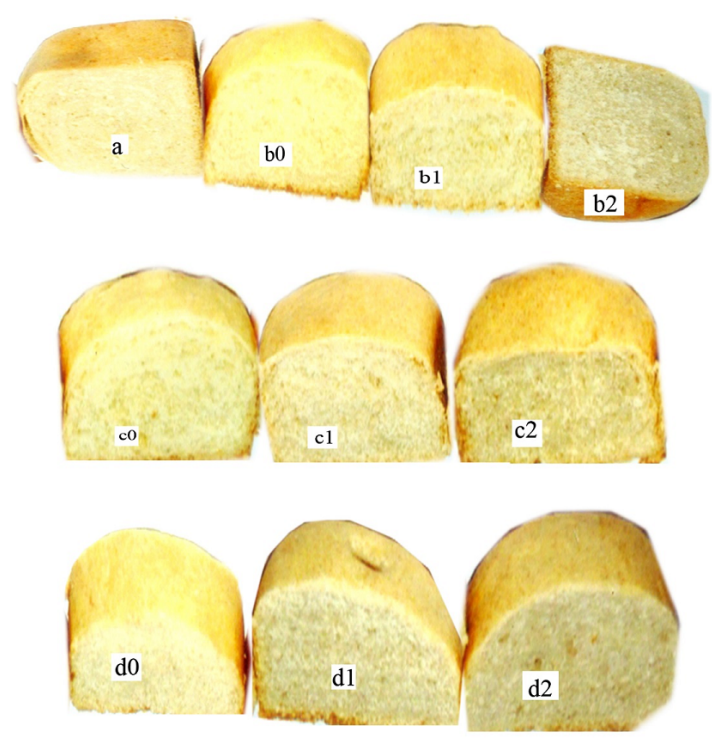

Figure 2: Bread slices from wheat-cassava flour blends containing different levels $(\%, \mathrm{w} / \mathrm{w})$ of Grewia venusta mucilage

$\mathrm{a}=100 \%$ wheat flour (Control)

$\mathrm{b}=90: 10 \%$ wheat-cassava flour blends

$\mathrm{c}=80: 20 \%$ wheat-cassava flour blends

$\mathrm{d}=70: 30 \%$ wheat-cassava flour blends

Number 0,1 and 2 represent $0 \%, 1 \%$ and $2 \%$ mucilage, respectively

leavening agents. The length and width of the control and the samples of the loaves containing cassava flour and Grewia mucilage appeared to be dependent on the dimensions of the baking pans (Table 1). There was increasing presence and uniform distribution of air pockets in the bread crumbs due to Grewia mucilage inclusion. This resulted in improved spongy characteristics of the bread crumbs for the flours containing mucilage, for which reason panellists scored the crumbs higher than those without mucilage.

The weights of the fragments of bread loaves obtained upon slicing reduced with increasing level of cassava flour inclusion. Mucilage inclusion resulted in further reduction of fragments from the bread when sliced. This reduction in fragmentation is indicative of improved binding of the bread loaves by both the cassava flour and Grewia venusta mucilage. Improved binding would increase cohesiveness, which would lead to increased smoothness as noted earlier. It has been reported by Kohajdova et al. (2009) that 
Quality of bread from wheat-cassava flours | 197

Table 2: Proximate composition (\%, dry weight basis) of bread loaves prepared from wheat and cassava flour blends containing Grewia venusta mucilage

\begin{tabular}{llllllll}
\hline $\begin{array}{l}\text { WF: CF } \\
(\%)\end{array}$ & GG & Protein & Fat & $\begin{array}{l}\text { Dietary } \\
\text { fibre }\end{array}$ & Ash & Moisture & Carbohydrate \\
\hline $100: 0$ & $0^{*}$ & $18.1^{a}$ & $10.1^{a b}$ & $1.9^{a}$ & $0.9^{d}$ & $22.5^{a}$ & $46.5 \mathrm{f}$ \\
$90: 10$ & 0 & $12.1^{b}$ & $9.6^{b c}$ & $1.0^{c}$ & $0.9^{d}$ & $20.1^{b}$ & $56.3^{c}$ \\
$90: 10$ & 1.0 & $12.3^{b}$ & $10.1^{a b}$ & $1.1^{b c}$ & $1.1^{c d}$ & $22.0^{b}$ & $53.4^{d e}$ \\
$90: 10$ & 2.0 & $12.4^{b}$ & $10.7^{a}$ & $1.2^{b}$ & $1.1^{c d}$ & $22.2^{a}$ & $52.4^{e}$ \\
$80: 20$ & 0 & $11.5^{c}$ & $9.1^{c d}$ & $0.9^{c}$ & $0.9^{d}$ & $20.0^{d}$ & $57.6^{b}$ \\
$80: 20$ & 1.0 & $11.5^{c}$ & $9.6^{b c}$ & $1.0^{c}$ & $1.3^{c}$ & $20.6^{c}$ & $56.0^{c}$ \\
$80: 20$ & 2.0 & $11.6^{c}$ & $10.5^{a}$ & $1.0^{c}$ & $2.1^{b}$ & $20.9^{c}$ & $53.9^{d}$ \\
$70: 30$ & 0 & $9.9^{d}$ & $8.8^{d e}$ & $0.9^{c}$ & $0.9^{d}$ & $19.3^{e}$ & $60.2^{a}$ \\
$70: 30$ & 1.0 & $10.1^{c}$ & $7.3^{f}$ & $0.9^{c}$ & $1.8^{b}$ & $19.7^{d}$ & $60.2^{a}$ \\
$70: 30$ & 2.0 & $10.2^{c}$ & $8.1^{e}$ & $1.1^{b c}$ & $2.1^{a}$ & $20.5^{c}$ & $58.0^{b}$ \\
LSD & & $0.6^{c}$ & 0.7 & 0.2 & 0.3 & 0.4 & 1.0 \\
\hline
\end{tabular}

Values are means of duplicate determinations. Means in a given column with different superscripts differ significantly $(P \leq 0.05)$. WF $=$ Wheat flour, $\mathrm{CF}=$ Cassava flour, $\mathrm{GG}=$ Grewia mucilage powder (\% of flour blend).

*Control. LSD $=$ Least significant difference.

Table 3: Mean scores for sensory attributes of bread prepared from wheat-cassava flour blends containing Grewia venusta mucilage

\begin{tabular}{llllllll}
\hline $\begin{array}{l}\text { WF: CF } \\
(\%)\end{array}$ & GG & $\begin{array}{l}\text { Crust } \\
\text { colour }\end{array}$ & $\begin{array}{l}\text { Crumb } \\
\text { colour }\end{array}$ & Taste & Texture & Flavour & $\begin{array}{l}\text { Overall } \\
\text { acceptability }\end{array}$ \\
\hline $100: 0$ & $0^{*}$ & $6.6^{a}$ & $6.2^{a}$ & $6.5^{a}$ & $5.0^{b}$ & $5.8^{a}$ & $5.7^{a}$ \\
$90: 10$ & 0 & $6.4^{b}$ & $5.8^{b}$ & $6.2^{b}$ & $4.8^{a}$ & $5.6^{b}$ & $5.6^{a b}$ \\
$90: 10$ & 1.0 & $5.8^{b}$ & $5.3^{c}$ & $6.3^{a b}$ & $5.7^{d}$ & $5.5^{b c}$ & $5.3^{b}$ \\
$90: 10$ & 2.0 & $5.7^{b}$ & $5.8^{b}$ & $5.9^{c}$ & $6.4^{e}$ & $5.7^{a b}$ & $5.8^{a}$ \\
$80: 20$ & 0 & $6.2^{b}$ & $5.3^{c}$ & $5.7^{c}$ & $4.9^{a}$ & $5.5^{c}$ & $5.1^{b}$ \\
$80: 20$ & 1.0 & $5.2^{c}$ & $5.0^{d}$ & $6.3^{a b}$ & $5.7^{d}$ & $5.6^{b}$ & $5.5^{a b}$ \\
$80: 20$ & 2.0 & $6.4^{a}$ & $5.2^{c d}$ & $6.3^{a b}$ & $6.4^{e}$ & $5.7^{a b}$ & $5.7^{a}$ \\
$70: 30$ & 0 & $6.4^{a}$ & $6.0^{a}$ & $5.8^{c}$ & $5.9^{d}$ & $5.5^{c}$ & $5.3^{b}$ \\
$70: 30$ & 1.0 & $5.8^{b}$ & $6.2^{a}$ & $6.2^{b}$ & $5.3^{c}$ & $5.4^{c}$ & $5.4^{b}$ \\
$70: 30$ & 2.0 & $5.5^{b c}$ & $5.1^{c d}$ & $5.9^{c}$ & $6.3^{e}$ & $4.8^{d}$ & $5.6^{a b}$ \\
LSD & & $0.2^{c}$ & $0.2^{c}$ & $0.2^{c}$ & 0.3 & $0.2^{2}$ & 0.3 \\
\hline
\end{tabular}

Means within a column with the same superscripts are not significantly different $(P \geq 0.05)$. Samples were evaluated on a 7 point hedonic scale $(7=$ like extremely, 1 = dislike extremely). WF = Wheat flour; CF = Cassava flour; GG = Grewia venusta mucilage (\% of flour blend). $\mathrm{LSD}=$ Least significant difference.

$\mathrm{LSD}=\mathrm{L}$
${ }^{*}$ Control. 
gum arabic has good adhesive properties for use in glazes, toppings and it imparted smoothness when used as an emulsion stabilizer.

The results of the proximate analysis of bread loaves prepared from wheat and cassava flour blends containing $G$. venusta mucilage are presented in Table 2. Addition of cassava flour to wheat flour had a significant $(P \leq 0.05)$ dilution effect on the protein and dietary fibre contents of the bread loaves produced from the flour blends. The protein content of the $100 \%$ wheat bread decreased from 18.1 to $12.1 \%$ as a result of cassava flour addition. Olapade and Adeyemo (2014) observed similar reductions in protein content due to the increased level of cassava flour in wheat and cassava flour blends meant for cookie production. Inclusion of Grewia mucilage in the flours in the present study resulted in a marginal increase in the protein, dietary fibre and ash contents of the bread. The moisture content of the $100 \%$ wheat bread decreased from $22.5 \%$ to $20.1 \%$ for the bread produced from the $90: 10 \%$ flour blend. Addition of Grewia mucilage at $1 \%$ and $2 \%$ reversed the moisture contents to $22.0 \%$ and $22.2 \%$, respectively. The change in the moisture content of loaves for the 80:20\% and 70:30\% flour blends were similar to that for the $90: 10 \%$ blend. The Grewia mucilage enhanced the water retention of the loaves as proposed by Kohajdova et al. (2009).

The mean sensory scores of bread loaves prepared from wheat and cassava flour blends containing $G$. venusta mucilage as presented in Table 3 showed that the $100 \%$ wheat flour bread (control) was scored higher for both the crust and crumb colours compared to those that contained cassava flour and Grewia mucilage. The results suggest that Grewia venusta mucilage may be unsuitable with respect to the colour of bread produced from wheat flour of high percentage extraction. The mucilage may be more suitable for use after decolorization or if applied in the production of brown loaves, using wheat flour of low extraction or flour containing caramel. Generally, the taste and flavour of the bread containing cassava flour were scored lower than those of the control. Addition of mucilage did not influence the scores significantly. The texture of bread loaves produced with the flour blends received significantly $(P \leq 0.05)$ lower scores than those for the control.
However, inclusion of Grewia venusta mucilage in the flour blends significantly improved the texture of the bread as indicated by the scores.

\section{Conclusions}

The weight, volume and physical dimensions of the bread loaves produced from wheat and cassava flour blends increased due to Grewia venusta mucilage inclusion. The bread crumbs became progressively spongy with increasing level of mucilage in the flours and their texture received higher sensory scores than those of the control. Cassava flour inclusion resulted in the decrease of protein, fat and fibre contents of the bread. Grewia venusta mucilage addition marginally increased the levels of these nutrients relative to those of the bread without mucilage. The mucilage may serve as a useful additive in wheat and cassava composite flours.

\section{References}

Almazan, A. M. (1990). Effect of cassava flour variety and concentration on bread loaf quality. Cereal Chemistry, 67(1), 97-99.

AOAC - International, Association of Official Analytical Chemists. (2005). Official methods of analysis of the association of official analytical chemists. 18th ed. Maryland: AOAC International.

Asghar, A., Anjum, F. M., Tariq, M. W., \& Hussain, S. (2005). Effect of carboxy methyl cellulose and gum arabic on the stability of frozen dough for bakery products. Turkish Journal of Biology, 29(4), 237-241. Retrieved from http://search.ebscohost.com/ login. aspx ? direct = true \& AuthType =ip , uid \& db=a9h \& AN $=19255711 \&$ site $=$ edslive\&scope $=$ site\&authtype $=i p$, cookie, uid

Asif-Ul-Alam, S. M., Islam, M. Z., Hoque, M. M., \& Monalisa, K. (2014). Effects of drying on the physicochemical and functional properties of green banana (Musa sapientum) flour and development of baked product. American Journal of Food Science and Technology, 2(4), 128-133. Retrieved from http://pubs.sciepub.com/ajfst/2/4/4 
Badifu, G. I. O., Chima, C. E., Ajayi, Y. I., \& Ogori, A. F. (2005). Influence of mango mesocarp flour supplement to micronutrient, physical and organoleptic qualities of wheat-based bread. Nigerian Food Journal, 23(1), 59-68.

Defloor, I., Nys, M., \& Delcour, J. A. (1993). Wheat-starch, cassava starch, and cassava flour impairment of the breadmaking potential of wheat-flour. Cereal Chemistry, $70(5), 526-530$.

Delcour, J. A., Vanhamel, S., \& Hoseney, R. C. (1991). Physicochemical and functionalproperties of rye nonstarch polysaccharides .2. impact of a fraction containing water-soluble pentosans and proteins on gluten-starch loaf volumes. Cereal Chemistry, 68(1), 72-76.

Eduardo, M., Svanberg, U., Oliveia, J., \& Ahrne, L. (2013). Effect of cassava flour characteristics on properties of cassava-wheat-maize composite bread types. International Journal of Food Science, 1(10). doi:10.1155/ 2013/305407

Eriksson, E., Koch, K., Tortoe, C., Konor, P. T., \& Oduro-Yeboah, C. (2014). Evaluation of the physical and sensory characteristics of bread produced from three varieties of cassava and wheat composite flours. Food and Public Health, 4(5), 214-222.

Hashmi, I. (2007). Sensory evaluation techniques. In 18th Annual IOAM Conference (MEA District), Muscat Oman (pp. 1-30). Retrieved from www.iaom-mea.com/edumat/ dec11/sessions/tech10-agf

Igbabul, B., Num, G., \& Amove, J. (2014). Quality evaluation of composite bread produced from wheat, maize and orange fleshed sweet potato flours. American Journal of Food Science and Technology, 2(4), 109-115. Retrieved from http://pubs.sciepub.com / ajfst $/ 2 / 4 / 1$

IITA - International Institute of Tropical Agriculture. (2005). Integrated cassava project: promoting the cassava industry. Retrieved from www.cassabiz.org/p

Khalil, A. H., Mansour, E. H., \& Dawoud, F. M. (2000). Influence of malt on rheological and baking properties of wheat-cassava composite flours. Lebensmittel-wissenschaft
Und-technologie-food Science and Technology, 33(3), 159-164. doi:10.1006/fstl.1999. 0629

Kohajdova, Z., Karovicova, J., \& Schmidt, S. (2009). Significance of emulsifiers and hydrocolloids in bakery industry. Acta Chimica Slovaca, 2(1), 46-61.

Koko, C. A., Kouame, B. K., Assidjo, E., \& Amani, G. (2014). Characterization and utilization of fermented cassava flour in breadmaking and placali preparation. International Journal of Biological and Chemical Sciences, 8(6), 2478-2493.

Kumar, J. V., Sati, P. O., \& Singh, R. (2011). A potential natural tablet binder from Grewia optiva. Scholars Research Library, 3(3), 120-127.

Miller, R. A. \& Hoseney, R. C. (1993). The role of xanthan gum in white layer cakes. Cereal Chemistry, $70(5), 585-588$.

Nenonene, A. Y., Koba, K., Sanda, K., \& Rigal, L. (2009). Composition and binding properties of mucilages from stem bark of grewia venusta and calyx of bombax costatum, two tropical plants growing wild in togo. Bangladesh Journal of Scientific and Industrial Research, 44(2), 247-253.

Nep, E. \& Conway, B. (2010). Characterization of grewia gum, a potential pharmaceutical excipient. Journal of Excipients and Food Chemicals, 1(1), 30-40. Retrieved from https: / / ojs . abo.fi / ojs / index.php / jefc/ article/view/12

Nwanekezi, E. C. (2013). Composite flours for baked products and possible challenges: a review. Nigerian Food Journal, 31(2), 817. doi:10.1016/S0189-7241(15)30071-0

Ogori, A. F. \& Gana, J. (2014). Effect of cassava starch flour seeding on functional properties of cissus gum stem and root ( $\mathrm{Cis}$ sum Populnea) stem and root gum. Journal of Environmental Science and Technology, 7(2), 1-4. Retrieved from http: / / www . iosrjournals.org

Ohimain, E. I. (2014a). Review of cassava bread value chain issues for actualization of the $40 \%$ cassava bread production in nigeria. Journal of Science Research Reports, 3(9), 1220-1231. doi:10.9734/JSRR/2014/8825 
Ohimain, E. I. (2014b). The prospects and challenges of cassava inclusion in wheat bread policy in nigeria. International Journal of Science, Technology and Society, 2(1), 617. doi:10.11648/j.ijsts.20140201.12

Oladunmoye, O. O., Akinoso, R., \& Olapade, A. A. (2010). Evaluation of some physicalchemical properties of wheat, cassava, maize and cowpea flours for bread making. Journal of Food Quality, 33(6), 693-708. doi:10.1111/j.1745-4557.2010.00351.x

Olapade, A. A. \& Adeyemo, M. A. (2014). Evaluation of cookies produced from blends of wheat, cassava and cowpea flours. International Journal of Food Studies, 3(2).

Rojas, J. A., Rosell, C. M., \& de Barber, C. B. (1999). Pasting properties of different wheat flour-hydrocolloid systems. Food Hydrocolloids, 13(1), 27-33. doi:10.1016/ S0268-005X(98)00066-6

Sanni, L. O., Maziya-Dixon, B., Akanya, J. N., Okoro, C. I., Alaya, Y., Egwuonwu, C. V., ... Lemchi, J. (2005). Standards for cassava products and guidelines for export. (pp. 11-35). IITA.

Sedlacek, T. \& Horcicka, P. (2011). Development of a small-scale variant of the rapid mix test experimental bread baking. Czech Journal of Genetics and Plant Breeding, $47(3), 123-127$.

Shittu, T. A., Raji, A. O., \& Sanni, L. O. (2007). Bread from composite cassava-wheat flour: i. effect of baking time and temperature on some physical properties of bread loaf. Food Research International, 40(2), 280290. doi:10.1016/j.foodres.2006.10.012

Singh-Ackbarali, D. \& Maharaj, R. (2014). Sensory evaluation as a tool in determining acceptability of innovative products developed by undergraduate students in food science and technology at the university of trinidad and tobago. Journal of Curriculum and Teaching, 3(1), 10.

Steel, R. G. D., Torrie, J. H., \& Dickey, D. A. (1997). Principles and procedures of statistics: a biological approach. McGraw-Hill.

Svensson, L. (2012). Design and performance of small scale sensory consumer tests (Master's thesis, The Faculty of Natural Resources and Agricultural Sciences. Swedish
University of Agricultural Science. Uppsala). Retrieved from http://stud.epsilon. slu.se

Wang, A. \& Wang, W. (2013). Gum-gcopolymers: synthesis, properties, and applications. In S. Kalia \& M. W. Sabaa (Eds.), Polysaccharide based graft copolymers (pp. 149-203). Berlin, Heidelberg: Springer Berlin Heidelberg. doi:10.1007/ 978-3-642-36566-9_5 